\title{
Effects of Casein and Glucose on Responses of Cows Fed Diets Based on Restrictively Fermented Grass Silage
}

\author{
A. Vanhatalo, T. Varvikko, and P. Huhtanen \\ Animal Production Research, MTT, Agrifood Research Finland, \\ FIN-31600 Jokioinen, Finland
}

\begin{abstract}
This study was conducted to investigate whether well fed dairy cows given restrictively fermented grass silage diet will respond to incremental glucose and amino acid supply at early stage of lactation. Four rumen-cannulated Finnish Ayrshire cows were used in a $4 \times 4$ Latin square experiment with 14 -d periods. The cows were fed good quality restrictively fermented grass silage ensiled with a formic acid additive for ad libitum intake. A concentrate mixture consisting of barley (85\%) and solvent extracted rapeseed meal (11.4\%) was given at a rate of $9 \mathrm{~kg} / \mathrm{d}$. The four treatments were continuous abomasal infusions of water (control), casein $300 \mathrm{~g} / \mathrm{d}$, glucose $300 \mathrm{~g} / \mathrm{d}$, and casein $300 \mathrm{~g} / \mathrm{d}+$ glucose $300 \mathrm{~g} / \mathrm{d}$. The infusions had only minor effects on feed intake, diet digestibility, or rumen fermentation pattern. Both casein and glucose infusions increased milk, protein and lactose yields the effects being partly additive on the combined infusion. Infused casein increased milk protein and urea as well as plasma urea concentrations. Both casein and glucose tended to increase plasma glucose concentration. Casein increased arterial plasma concentrations of essential amino acids (EAA), branched-chain AA (BCAA), and total AA (TAA). Both casein and glucose, although glucose usually less than casein, increased arteriovenous differences of EAA, nonessential AA, BCAA, and TAA. Extraction efficiencies of AA were higher for glucose than for casein. Mammary plasma flow was at highest on the control diet, but reduced owing to infused nutrients, the reduction being less with combined rather than separate infusions of casein and glucose. Based on the partly additive increases in milk production parameters and changes in plasma metabolites, it is suggested that glucose alone increased milk protein yield by sparing AA from hepatic utilization, while casein increased both supply of AA and glucose. It was concluded that cows at early stage of lactation fed diets comprising of restrictively fermented
\end{abstract}

Received October 2, 2002.

Accepted May 1, 2003.

Corresponding author: A. Vanhatalo; e-mail: aila.vanhatalo@ mtt.fi. grass silage and a cereal-based concentrate suffer from both limited AA and glucose supplies.

(Key words: grass silage, dairy cow, glucose, amino acids)

Abbreviation key: AV = arteriovenous, BCAA = branched-chain AA, $\mathbf{C}=$ casein treatment, $\mathbf{C G}=$ casein and glucose treatment, EAA = essential AA, $\mathbf{G}=$ glucose treatment, $\mathbf{M E}=$ metabolizable energy, $\mathbf{N E A A}=$ nonessential AA, TAA = total AA.

\section{INTRODUCTION}

Rumen fermentation of cows fed large amounts of restrictively fermented grass silage is characterized by a high efficiency of microbial protein synthesis but with a low production of propionate in the rumen (Huhtanen, 1998). Recent studies show that protein supplementation of grass silage-cereal diets increases RUP but does not affect microbial flow, which still comprises majority of the protein flow entering to the small intestine (Ahvenjärvi et al., 1999; Korhonen et al., 2002). Therefore, AA supply of cows fed grass silage diets is highly determined by the features of microbial protein, which is, however, a not quite optimal protein source for milk production. As microbial protein is poor in His relative to milk protein (Clark et al., 1992), it is not surprising that His is often obtained as the first limiting AA in milk production on grass silage-based diets (Vanhatalo et al., 1999, Kim et al., 1999; Korhonen et. al., 2000). It is also well known that a supplementary AA supply in the form of postruminally infused casein gives a consistent increase in milk production of grass silage-fed cows (Choung and Chamberlain, 1993a; Huhtanen et al., 1997; Vanhatalo et al., 2003).

On the other hand, given that ruminal propionate production is low and grass silage diet is poor in postruminal starch, the glucose supply of the cows may be limited with these diets (Huhtanen, 1998; Hurtaud et al., 2000). It has been suggested that in this dietary situation, part of the AA in protein entering the lower tract may be utilized for gluconeogenesis decreasing mammary AA availability for milk protein synthesis (Huhtanen, 1998; Vanhatalo et al., 2003). Hepatic me- 
tabolism of propionate and glucogenic AA into glucose synthesis is regulated to a great extent by the availability of these substrates (Danfær,1995). However, increasing glucose supply either by ruminal propionate infusions or postruminal glucose infusion has given inconsistent results. Sometimes they have increased yields of milk, protein, and lactose (Huhtanen et al., 1998; Huhtanen et al. 2002) but not always (Kim et al., 2000; Vanhatalo et al., 2003). Sufficient glucose supply from the basal diet may explain the lack of responses to glucogenic substrates (Kim et al., 2000), but it is also possible that some other nutrient but glucose, such as first-limiting AA, has primarily limited milk production (Vanhatalo et al., 2003). This is supported by the recent finding that by increasing the supply of glucose efficiency of utilizing of the first-limiting AA, His, could be improved (Huhtanen et al., 2002). Therefore, question arises whether the milk production responses on grass silage-based diets are primarily restricted by limited supply of glucose or by limited supply of AA, or by both glucose and AA.

Thus, this experiment was designed to study if glucose supply of dairy cows fed restrictively fermented grass silage supplemented with a cereal-based concentrate is sufficient and if responses to AA in terms of casein are restricted by limited supply of glucose. The infusion trial was conducted with cows at early stage of lactation to evaluate if the negligible response to glucose was related to the low production level of cows in our recent experiment (Vanhatalo et al., 2003). Casein and glucose were infused both separately and in combination into the abomasum of cows to look at the effects of the infusates on milk production and plasma metabolites. The control diet was formulated to fulfil the requirements of nutrient supply in terms of total supply of metabolizable AA and energy (Tuori et al., 2000).

\section{MATERIALS AND METHODS}

\section{Cows and Management}

Four Finnish Ayrshire cows at second, fourth, or fifth lactation averaging 54 DIM (SD = 9.7) were used in the experiment. The $\mathrm{BW}$ of cows was $534 \mathrm{~kg}(\mathrm{SD}=64.4)$ at the beginning, and $550 \mathrm{~kg}(\mathrm{SD}=60.2)$ at the end of the experiment. They were fitted with rumen cannulas, and infusion catheters were introduced into their abomasum as described previously (Varvikko et al. 1999). The cows were kept in individual stanchions and milked twice daily at 0700 and $1630 \mathrm{~h}$. They had a free access to restrictively fermented grass silage to allow refusals of $10 \%$ of the total consumption. The cows had also free access to water and salt block. The concentrate mixture given to the cows at a rate of $9 \mathrm{~kg} / \mathrm{d}$ on a fresh weight basis consisted of barley (85\%), solvent-extracted rapeseed meal (11.4\%) (Rehuraisio Oy, Raisio, Finland), mineral mixture (2.8\%) (Viher Hertta-Minera Muro, Suomen Rehu Oy, Helsinki, Finland), calcium carbonate $(0.6 \%)$, and sodium chloride $(0.2 \%)$. Adjustment of concentrate supplementation in the basal diet was done in order to avoid a shortage of RDP and also to avoid an excessive supply of RUP, because it could possibly mask the differences between the treatments. Grass silage was prepared from primary growth of timothy (Phleum pratense) and meadow fescue (Festuca pratensis) sward. The grass was cut with a disc-mower and harvested after a wilting period of 4 to $6 \mathrm{~h}$ using a precision-chop forage harvester. It was ensiled into a bunker silo of 50-tonne capacity using formic acid-based additive (5 L/tonne of grass; in kg of additive: $800 \mathrm{~g}$ of formic acid and $20 \mathrm{~g}$ of orthophosphoric acid).

\section{Experimental Procedures and Chemical Analyses}

The experiment was designed as a $4 \times 4$ Latin square with 14-d experimental periods, of which the latter $5 \mathrm{~d}$ formed the collection period. The four treatments were continuous abomasal infusions of 1 ) water (Control), 2) casein $300 \mathrm{~g} / \mathrm{d}(\mathbf{C}), 3)$ glucose $300 \mathrm{~g} / \mathrm{d}(\mathbf{G})$, and 4) casein $300 \mathrm{~g} / \mathrm{d}+$ glucose $300 \mathrm{~g} / \mathrm{d}$ (CG). Casein was given as sodium caseinate (Kainuun Osuusmeijeri, Sotkamo, Finland) and glucose as dextrose (Xyrofin Ltd, Helsinki, Finland). Both casein and glucose were dissolved in 6 $\mathrm{L}$ of water, and the solution was infused continuously via a peristaltic pump as described previously (Varvikko et al., 1999). Infusion equipment was checked daily during the experiment to ensure correct placement in the abomasum. Feed intake and milk yield of cows were recorded daily but data from collection period only were used in statistical analyses. Feeds were sampled for chemical analyses during each collection period. Milk samples were taken on four consecutive milkings on each collection period. In addition, a separate milk sample from evening and morning milking was taken for urea determination. Rumen fluid was sampled four times and blood from the mammary and tail vein three times during the feeding cycle on the last day of each experimental period. Both of these samples were taken just before the morning feeding and at 3-h intervals thereafter. In order to evaluate energy status of the cows, total digestibility of diets was measured using acid-insoluble ash as an internal marker. Fecal grab samples were collected for $5 \mathrm{~d}$ for this purpose. Sampling of feed, milk, blood, rumen fluid, and feces have been described in more detail previously (Varvikko et al., 1999).

The chemical composition of feeds and feces were analysed as described earlier (Varvikko et al., 1999). 
The procedures for VFA of grass silage and rumen fluid, and plasma glucose, NEFA and BHBA, as well as plasma AA and urea were described in detail in our previous papers (Varvikko et al., 1999; Vanhatalo et al., 2003). Plasma insulin was colorimetrically analyzed with Phadeseph Insulin RIA kit (cat. no. 10-9169-01, Pharmacia \& Upjohn Diagnostics AB, Uppsala, Sweden). Plasma samples were reduced to period pools for each cow before the AA analyses. Milk fat, protein, lactose, and urea contents were analyzed as described previously (Varvikko et al., 1999).

\section{Calculations and Statistical Analyses}

Mammary extraction and uptake of blood metabolites and AA and plasma flow were calculated as described earlier (Vanhatalo et al., 1999). In brief, mammary extraction efficiency of blood metabolites and AA were calculated as arteriovenous (AV) difference divided by arterial concentration. Mammary plasma flow was estimated in reference to Phe and Tyr output in milk protein by application of Fick principle assuming that Phe and Tyr are incorporated directly into milk protein without no further metabolism or synthesis of these two AA.

Data were analyzed by the ANOVA for Latin square: cow (d.f. 3), period (d.f. 3), treatment (d.f. 3), and the residual effects (d.f. 6) were the sources of variation. The general linear models procedure of SAS (1996) was used. The data for rumen fermentation and blood metabolites except for plasma AA were analyzed by the ANOVA using split-plot approach model including cow, period, treatment, whole-plot error, time, interaction between time and the treatment, and subplot error. However, as there were not any significant $(P>0.05)$ treatment $\times$ time effects, data were averaged over time for all rumen fermentation and blood metabolite parameters. Treatment effects were further separated into a single d.f. comparison by orthogonal contrasts to evaluate effects of: 1) casein (control + G vs. C + CG), 2) glucose (control $+\mathrm{C}$ vs. $\mathrm{G}+\mathrm{CG}$ ), and 3 ) an interaction between casein and glucose (control $+\mathrm{CG}$ vs. $\mathrm{C}+\mathrm{G}$ ).

\section{RESULTS}

\section{Characteristics of the Basal Diet}

The chemical composition of grass silage and concentrate used in the experiment are presented in Table 1. Grass silage fed was of high quality both in terms of nutrient content and fermentation characteristics. The in vitro digestibility of silage $\mathrm{OM}$ was high, and the high content of water soluble carbohydrates and low contents of fermentation acids and ammonia $\mathrm{N}$ in grass silage indicated restricted fermentation in the silo. Feed
Table 1. Chemical composition of feedstuffs.

\begin{tabular}{|c|c|c|}
\hline & Grass silage & Concentrate $^{1}$ \\
\hline $\mathrm{pH}$ & \multicolumn{2}{|l|}{4.12} \\
\hline $\mathrm{DM}, \%$ & 29.2 & $\begin{array}{r}88.1 \\
(\% \text { of } \mathrm{DM})\end{array}$ \\
\hline Ash & 8.4 & 6.4 \\
\hline $\mathrm{CP}$ & 17.8 & 15.3 \\
\hline NDF & 52.7 & 22.9 \\
\hline Water soluble carbohydrates & 8.5 & \\
\hline Lactic acid & 3.8 & \\
\hline Acetic acid & 1.6 & \\
\hline Propionic acid & 0.03 & \\
\hline Butyric acid & 0 & \\
\hline Ammonia $\mathrm{N}, \%$ of $\mathrm{N}$ & 3.5 & \\
\hline Soluble $\mathrm{N}, \%$ of $\mathrm{N}$ & 67.5 & \\
\hline $\begin{array}{l}\text { In vitro cellulase digestibility, } \\
\% \text { of OM }\end{array}$ & 77.3 & \\
\hline
\end{tabular}

${ }^{1}$ Concentrate was a mixture of barley $(85 \%)$, rapeseed meal $(11.4 \%)$ and minerals (3.6\%). The mineral mixture contained $16 \%$ of $\mathrm{Ca}, 6.4 \%$ of $\mathrm{P}, 9 \%$ of $\mathrm{Na}$ and $8 \%$ of $\mathrm{Mg}, 150,000 \mathrm{IU}$ of vitamin $\mathrm{A} / \mathrm{kg}, 100,000$ $\mathrm{IU}$ of vitamin $\mathrm{D} / \mathrm{kg}$, and $500 \mathrm{mg}$ of vitamin $\mathrm{E} / \mathrm{kg}$. It also contained trace elements as follows (per kg): $500 \mathrm{mg}$ of $\mathrm{Cu}, 10 \mathrm{mg}$ of Se, 3000 $\mathrm{mg}$ of $\mathrm{Zn}, 8 \mathrm{mg}$ of Mo, $10 \mathrm{mg}$ of Co, $1000 \mathrm{mg}$ of $\mathrm{Mn}$, and $100 \mathrm{mg}$ of I.

intake, rumen fermentation, and diet digestibility are shown in Table 2. The grass silage DMI was high. However, cows refused some of the concentrates on each treatment probably owing to the high quality grass silage freely available. Both casein $(P=0.11)$ and glucose $(P=0.08)$ infusions tended to reduce silage intake. $\mathrm{Ru}-$ men fermentation parameters or digestibility of nutrients were not significantly $(P>0.05)$ affected by the treatments, except for the slightly reduced NDF digestibility of the diet when glucose alone was infused $(P<$ 0.05 for $\mathrm{C} \times \mathrm{G}$ interaction). Digestibility of $\mathrm{OM}$ and $\mathrm{CP}$ tended $(P \geq 0.07)$ to increase owing to infusion of casein.

\section{Milk Production Responses}

Milk production data are shown in Table 3. Both casein $(P=0.06)$ and glucose $(P=0.07)$ infusions increased milk yield. Increases in milk yields due to casein and glucose were partly additive $(\mathrm{C}$ and $\mathrm{G}$ alone $+1.8 \mathrm{~kg} / \mathrm{d}, \mathrm{C}$ and $\mathrm{G}$ together $+2.8 \mathrm{~kg} / \mathrm{d}$ ). Casein infusion increased $(P<0.01)$ milk protein content $(31.9$ vs. 30.6 $\mathrm{g} / \mathrm{kg})$, and tended $(P=0.10)$ to decrease milk fat content (37.0 versus $40.0 \mathrm{~g} / \mathrm{kg}$ ), whereas glucose infusion did not affect $(P>0.10)$ these parameters. Infusion of casein increased $(P<0.01)$ milk urea concentration $(28.8$ vs. $26.1 \mathrm{mg} / \mathrm{dl})$ and infusion of glucose tended $(P=0.08)$ to decrease it (26.7 versus $28.2 \mathrm{mg} / \mathrm{dl})$. Increases in milk protein yields due to casein $(P<0.01)$ and glucose $(P=$ $0.10)$ infusions were also partly additive $(+117,+74$, and $138 \mathrm{~g} / \mathrm{d}$ for $\mathrm{C}, \mathrm{G}$, and $\mathrm{CG}$, respectively). Infusion of casein tended to increase $(P=0.10)$, and infusion of glucose increased $(P<0.05)$ milk lactose yield. 
Table 2. Least squares means for feed intake, rumen fermentation, and digestibility of diets.

\begin{tabular}{|c|c|c|c|c|c|c|c|c|}
\hline & \multicolumn{4}{|c|}{ Nutrients infused postruminally $^{1}$} & \multirow[b]{2}{*}{ SEM } & \multicolumn{3}{|c|}{$P$-value } \\
\hline & Control & $\mathrm{C}$ & G & CG & & $\mathrm{C}$ & $\mathrm{G}$ & $\mathrm{C} \times \mathrm{G}$ \\
\hline \multicolumn{9}{|l|}{$\mathrm{DMI}, \mathrm{kg} / \mathrm{d}$} \\
\hline Silage & 13.0 & 12.0 & 12.0 & 11.7 & 0.32 & 0.11 & 0.08 & 0.39 \\
\hline Concentrate & 6.8 & 7.3 & 7.5 & 6.9 & & & & \\
\hline Total $^{2}$ & 19.8 & 19.6 & 19.8 & 19.2 & 0.37 & 0.38 & 0.54 & 0.54 \\
\hline $\mathrm{ME}$ intake, $\mathrm{MJ} / \mathrm{d}^{3}$ & 222 & 223 & 217 & 229 & 4.3 & 0.18 & 0.91 & 0.21 \\
\hline \multicolumn{9}{|l|}{ Rumen fermentation } \\
\hline $\mathrm{pH}$ & 6.26 & 6.10 & 6.04 & 6.07 & 0.068 & 0.39 & 0.10 & 0.22 \\
\hline $\mathrm{NH}_{3}-\mathrm{N}, \mathrm{mmol} / \mathrm{L}$ & 9.23 & 9.97 & 8.72 & 8.37 & 0.796 & 0.81 & 0.24 & 0.52 \\
\hline VFA, mmol/L & 120 & 126 & 123 & 128 & 3.5 & 0.18 & 0.49 & 0.87 \\
\hline \multicolumn{9}{|c|}{ Molar proportion, $\mathrm{mmol} / 100 \mathrm{mmol}$} \\
\hline Acetate & 65.5 & 64.5 & 64.1 & 64.0 & 0.49 & 0.30 & 0.10 & 0.42 \\
\hline Propionate & 18.4 & 18.7 & 19.2 & 19.3 & 0.36 & 0.56 & 0.10 & 0.79 \\
\hline Butyrate & 11.4 & 11.9 & 11.7 & 11.9 & 0.34 & 0.28 & 0.74 & 0.73 \\
\hline \multicolumn{9}{|l|}{ Digestibility, \% } \\
\hline $\mathrm{OM}$ & 73.2 & 73.4 & 71.7 & 75.3 & 0.86 & 0.06 & 0.82 & 0.10 \\
\hline CP & 68.9 & 70.7 & 67.6 & 71.9 & 1.44 & 0.07 & 0.99 & 0.39 \\
\hline NDF & 65.9 & 65.1 & 63.6 & 66.7 & 0.79 & 0.21 & 0.68 & 0.05 \\
\hline
\end{tabular}

${ }^{1}$ Control = No infusion of nutrients; $\mathrm{C}=300 \mathrm{~g} / \mathrm{d}$ of casein infused postruminally; $\mathrm{G}=300 \mathrm{~g} / \mathrm{d}$ of glucose infused postruminally; $\mathrm{CG}=300 \mathrm{~g} / \mathrm{d}$ of casein and $300 \mathrm{~g} / \mathrm{d}$ of glucose infused postruminally.

${ }^{2}$ Total DMI including infused nutrients.

${ }^{3}$ Metabolizable energy (ME) intake of cows as calculated on the basis of digestibility of OM measured and including infused nutrients.

\section{Plasma Energy Metabolites and AA}

Mammary plasma flow, arterial concentrations, calculated AV differences, extractions, and mammary uptakes of plasma energy-yielding metabolites as well as insulin concentration are given in Table 4. Combined infusion of nutrients reduced plasma flow less than infusion of these nutrients separately as indicated by an interaction between casein and glucose infusions in mammary plasma flows expressed as $\mathrm{L} / \mathrm{d}(P=0.05)$ or $\mathrm{L} /$ $\mathrm{kg}$ of milk $(P=0.07)$. Both casein and glucose infusions tended $(P=0.11)$ to increase arterial glucose concentra- tion, but neither of them affected $(P>0.05)$ insulin or NEFA concentrations. Infusion of glucose decreased $(P$ $<0.01)$ arterial concentration of BHBA. Infusion of glucose was also associated to the decreases in mammary AV difference of glucose $(P=0.10)$ and BHBA $(P<0.05)$, extraction of glucose $(P=0.06)$, and uptake of BHBA $(P=0.07)$. A significant interaction $(P=0.02)$ between casein and glucose infusions in mammary extraction of BHBA indicated that infusion of casein alone increased extraction but in the presence of glucose infusion decreased it.

Table 3. Least squares means for milk yield and milk components.

\begin{tabular}{|c|c|c|c|c|c|c|c|c|}
\hline & \multicolumn{4}{|c|}{ Nutrients infused postruminally $^{1}$} & \multirow[b]{2}{*}{ SEM } & \multicolumn{3}{|c|}{$P$-value } \\
\hline & Control & $\mathrm{C}$ & $\mathrm{G}$ & CG & & $\mathrm{C}$ & $\mathrm{G}$ & $\mathrm{C} \times \mathrm{G}$ \\
\hline \multicolumn{9}{|l|}{ Yield, kg/d } \\
\hline Milk & 32.3 & 34.1 & 34.1 & 35.1 & 0.61 & 0.06 & 0.07 & 0.55 \\
\hline $\mathrm{ECM}^{2}$ & 31.3 & 33.0 & 33.4 & 32.9 & 0.56 & 0.35 & 0.12 & 0.10 \\
\hline \multicolumn{9}{|c|}{ Milk composition, $\mathrm{g} / \mathrm{kg}$} \\
\hline Protein & 30.3 & 31.9 & 30.8 & 31.8 & 0.34 & 0.01 & 0.68 & 0.41 \\
\hline Lactose & 48.3 & 48.3 & 48.8 & 48.8 & 0.19 & 0.32 & 0.16 & 0.32 \\
\hline Fat & 40.2 & 38.1 & 39.8 & 35.9 & 1.56 & 0.10 & 0.44 & 0.58 \\
\hline Urea, mg/dl & 26.8 & 29.5 & 25.3 & 28.0 & 0.74 & 0.01 & 0.08 & 0.99 \\
\hline \multicolumn{9}{|l|}{ Yield, g/d } \\
\hline Protein & 971 & 1088 & 1045 & 1109 & 24.5 & 0.01 & 0.10 & 0.32 \\
\hline Lactose & 1558 & 1645 & 1659 & 1693 & 31.2 & 0.10 & 0.05 & 0.42 \\
\hline Fat & 1266 & 1288 & 1347 & 1249 & 37.0 & 0.34 & 0.60 & 0.16 \\
\hline
\end{tabular}

${ }^{1}$ Control $=$ No infusion of nutrients; $\mathrm{C}=300 \mathrm{~g} / \mathrm{d}$ of casein infused postruminally; $\mathrm{G}=300 \mathrm{~g} / \mathrm{d}$ of glucose infused postruminally; $\mathrm{CG}=300 \mathrm{~g} / \mathrm{d}$ of casein and $300 \mathrm{~g} / \mathrm{d}$ of glucose infused postruminally.

${ }^{2} \mathrm{ECM}=$ Energy-corrected milk; calculated according to Sjaunja et al. (1990). 
Table 4. Least squares means for arterial plasma insulin concentration, mammary plasma flow, arterial plasma concentrations, extractions, arteriovenous (AV) differences, and mammary uptake of energy metabolites.

\begin{tabular}{|c|c|c|c|c|c|c|c|c|}
\hline & \multicolumn{4}{|c|}{ Nutrients infused postruminally $^{1}$} & \multirow[b]{2}{*}{ SEM } & \multicolumn{3}{|c|}{$P$-value } \\
\hline & Control & $\mathrm{C}$ & G C & G & & $\mathrm{C}$ & G & $\mathrm{C} \times \mathrm{G}$ \\
\hline $\begin{array}{l}\text { Insulin, mU/L } \\
\text { Mammary plasma flow }\end{array}$ & 7.9 & 8.3 & 8.4 & 7.2 & 0.92 & 0.63 & 0.77 & 0.42 \\
\hline $\mathrm{L} / \mathrm{d}$ & 20,592 & 14,360 & 14,028 & 17,415 & $2,022.5$ & 0.51 & 0.42 & 0.05 \\
\hline $\mathrm{L} / \mathrm{kg}$ of milk & 668 & 426 & 411 & 504 & 75.2 & 0.36 & 0.28 & 0.07 \\
\hline \multicolumn{9}{|l|}{ Glucose, mmol/L } \\
\hline Arterial & 3.21 & 3.23 & 3.23 & 3.33 & 0.030 & 0.11 & 0.10 & 0.24 \\
\hline Difference & 0.90 & 0.96 & 0.88 & 0.85 & 0.032 & 0.70 & 0.10 & 0.25 \\
\hline Extraction, \% & 28.5 & 29.8 & 27.5 & 25.8 & 1.38 & 0.85 & 0.06 & 0.21 \\
\hline Uptake, g/kg milk & 101.1 & 70.9 & 63.7 & 73.6 & 10.64 & 0.38 & 0.15 & 0.11 \\
\hline \multicolumn{9}{|l|}{ NEFA, mmol/L } \\
\hline Arterial & 0.16 & 0.13 & 0.13 & 0.14 & 0.016 & 0.78 & 0.66 & 0.51 \\
\hline Difference & 0.01 & 0.01 & -0.01 & 0.01 & 0.011 & 0.81 & 0.77 & 0.63 \\
\hline Extraction, \% & -11.8 & -7.8 & -28.2 & -8.6 & 6.11 & 0.46 & 0.59 & 0.62 \\
\hline Uptake, g/kg milk & -0.33 & 0.75 & -0.70 & 0.84 & 2.534 & 0.62 & 0.96 & 0.93 \\
\hline \multicolumn{9}{|l|}{ BHBA, mmol/L } \\
\hline Arterial & 0.99 & 0.99 & 0.77 & 0.73 & 0.033 & 0.77 & 0.01 & 0.81 \\
\hline Difference & 0.32 & 0.42 & 0.30 & 0.27 & 0.027 & 0.37 & 0.05 & 0.09 \\
\hline Extraction & 31.4 & 43.3 & 39.7 & 36.3 & 3.27 & 0.12 & 0.81 & 0.02 \\
\hline Uptake, g/kg milk & 22.1 & 19.0 & 12.5 & 13.5 & 3.44 & 0.78 & 0.07 & 0.58 \\
\hline
\end{tabular}

${ }^{1}$ Control $=$ No infusion of nutrients; $\mathrm{C}=300 \mathrm{~g} / \mathrm{d}$ of casein infused postruminally; $\mathrm{G}=300 \mathrm{~g} / \mathrm{d}$ of glucose infused postruminally; $\mathrm{CG}=300 \mathrm{~g} / \mathrm{d}$ of casein and $300 \mathrm{~g} / \mathrm{d}$ of glucose infused postruminally.

Arterial plasma AA and urea concentrations are given in Table 5. Infusion of casein increased $(P \geq 0.06)$ plasma urea, total AA (TAA), essential AA (EAA), and branched-chain AA (BCAA) concentrations, but had no effect on nonessential AA (NEAA) concentration. Of the individual AA, infusion of casein increased $(P \geq$ 0.02) concentration of His, Ile, Leu, Lys, Trp, Val, Cys, Orn, and Pro, whereas infusion of glucose increased $(P$ $\geq 0.02$ ) that of Asp and Gly. As for Orn, casein infusion alone increased concentration of Orn, the increase being, however, less in the presence of glucose infusion $(P<0.05$ for interaction $\mathrm{C} \times \mathrm{G})$.

Arteriovenous differences of AA by the mammary gland are presented in Table 6. Significant interactions $(P \geq 0.03)$ between casein and glucose in AV differences of TAA, EAA and BCAA indicated that casein increased the response variables mentioned but the increase was compromised by simultaneous infusion of glucose. The same was true $(P<0.03)$ for AV differences of His, Leu, Lys, Met, Val, and Orn. Significant interactions between casein and glucose $(P \geq 0.05)$ in AV differences of NEAA indicated that both of the infusions increased the response variable mentioned, but the effect was more pronounced when nutrients were infused separately rather than in combination. The same was found $(P<0.001)$ for AV difference of Phe.

Mammary extractions of AA are presented in Table 7. Mammary extraction of BCAA increased with glucose infusion, but the increase was compromised with simultaneous infusion of casein $(P<0.01$ for $\mathrm{C} \times \mathrm{G}$ interac- tion). Casein infusion decreased mammary extraction of His, especially in the presence of glucose infusion $(P$ $<0.04$ for $\mathrm{C} \times \mathrm{G}$ interaction). Mammary uptakes of AA (data not shown) were not affected by the nutrient infusions $(P>0.05)$ with the exception that infusion of glucose significantly $(P<0.02)$ reduced uptake of Arg. Uptakes of TAA were $29.8,34.6,32.4$, and $36.0 \mathrm{~g} / \mathrm{kg}$ of milk (SEM 2.40) for control, C, G, and CG treatments, respectively.

\section{DISCUSSION}

\section{Nutrient Supply}

Assuming metabolizable energy (ME) concentration of the control diet on the basis of the digestibility of OM measured the basal diet supplied about $101 \%$ of the $\mathrm{ME}$ and $104 \%$ of the amount of total AA required for the observed milk production (Tuori et al., 2000). As found earlier (Varvikko et al., 1999; Vanhatalo et al., 1999, Huhtanen et al. 2002), the nutrients infused did not significantly $(P>0.05)$ affect total DMI, rumen fermentation, or diet digestibility. The rumen fermentation pattern was in the range of that reported for diets comprising high amounts of restrictively fermented grass silage and a cereal-based concentrate (Huhtanen, 1998). However, the present proportion of propionate in the rumen was clearly higher and the proportion of butyrate lower as compared with the reported average values. Ammonia concentration in the rumen was high because of grass silage high in $\mathrm{CP}$. 
Table 5. Least squares means for arterial plasma AA and urea concentration ( $\mu \mathrm{mol} / \mathrm{L})$.

\begin{tabular}{|c|c|c|c|c|c|c|c|c|}
\hline \multirow[b]{2}{*}{$\mathrm{AA}^{2}$} & \multicolumn{4}{|c|}{ Nutrients infused postruminally ${ }^{1}$} & \multirow[b]{2}{*}{ SEM } & \multicolumn{3}{|c|}{$P$-value } \\
\hline & Control & $\mathrm{C}$ & $\mathrm{G}$ & CG & & $\mathrm{C}$ & G & $\mathrm{C} \times \mathrm{G}$ \\
\hline Arg & 68 & 79 & 60 & 72 & 6.5 & 0.12 & 0.28 & 0.91 \\
\hline His & 27 & 52 & 31 & 51 & 2.8 & 0.001 & 0.63 & 0.42 \\
\hline Ile & 108 & 142 & 104 & 122 & 5.6 & 0.001 & 0.07 & 0.21 \\
\hline Leu & 104 & 147 & 105 & 133 & 7.2 & 0.001 & 0.36 & 0.33 \\
\hline Lys & 87 & 126 & 100 & 114 & 8.3 & 0.02 & 0.97 & 0.17 \\
\hline Met & 22 & 27 & 26 & 27 & 2.5 & 0.27 & 0.37 & 0.50 \\
\hline Phe & 45 & 52 & 48 & 51 & 3.1 & 0.15 & 0.76 & 0.57 \\
\hline Thr & 116 & 134 & 132 & 136 & 10.0 & 0.31 & 0.38 & 0.51 \\
\hline Trp & 27 & 30 & 29 & 31 & 1.0 & 0.05 & 0.20 & 0.65 \\
\hline Val & 203 & 280 & 204 & 253 & 11.7 & 0.001 & 0.30 & 0.27 \\
\hline Ala & 227 & 250 & 260 & 254 & 17.1 & 0.64 & 0.33 & 0.41 \\
\hline Asn & 58 & 68 & 63 & 67 & 5.7 & 0.27 & 0.74 & 0.60 \\
\hline Asp & 5.4 & 6.2 & 6.5 & 6.8 & 0.25 & 0.09 & 0.02 & 0.29 \\
\hline Cit & 87 & 98 & 102 & 101 & 7.1 & 0.51 & 0.25 & 0.46 \\
\hline Cys & 21 & 27 & 25 & 27 & 1.2 & 0.02 & 0.17 & 0.14 \\
\hline Gln & 242 & 244 & 276 & 258 & 18.4 & 0.67 & 0.24 & 0.60 \\
\hline Glu & 50 & 52 & 51 & 50 & 2.2 & 0.79 & 0.87 & 0.49 \\
\hline Gly & 307 & 297 & 334 & 327 & 6.9 & 0.29 & 0.01 & 0.82 \\
\hline 3Methis & 3.3 & 3.4 & 3.3 & 3.8 & 0.32 & 0.47 & 0.57 & 0.62 \\
\hline Orn & 43 & 64 & 50 & 56 & 2.9 & 0.001 & 0.86 & 0.05 \\
\hline Pro & 80 & 125 & 91 & 122 & 9.1 & 0.01 & 0.66 & 0.44 \\
\hline Ser & 117 & 114 & 120 & 121 & 9.1 & 0.89 & 0.62 & 0.87 \\
\hline Tyr & 47 & 60 & 52 & 59 & 5.6 & 0.13 & 0.76 & 0.68 \\
\hline Tau & 33 & 39 & 45 & 39 & 2.7 & 0.99 & 0.07 & 0.07 \\
\hline BCAA & 415 & 570 & 412 & 507 & 24.1 & 0.001 & 0.23 & 0.26 \\
\hline EAA & 806 & 1069 & 837 & 990 & 51.3 & 0.01 & 0.66 & 0.32 \\
\hline NEAA & 1155 & 1244 & 1280 & 1291 & 67.6 & 0.49 & 0.25 & 0.58 \\
\hline TAA & 1961 & 2313 & 2117 & 2280 & 110.7 & 0.06 & 0.60 & 0.43 \\
\hline Urea & 4804 & 5582 & 4954 & 5331 & 224.7 & 0.04 & 0.83 & 0.41 \\
\hline
\end{tabular}

${ }^{1}$ Control = No infusion of nutrients; $\mathrm{C}=300 \mathrm{~g} / \mathrm{d}$ of casein infused postruminally; $\mathrm{G}=300 \mathrm{~g} / \mathrm{d}$ of glucose infused postruminally; $\mathrm{CG}=300 \mathrm{~g} / \mathrm{d}$ of casein and $300 \mathrm{~g} / \mathrm{d}$ of glucose infused postruminally.

${ }^{2} \mathrm{BCAA}=$ Branched-chain AA (Val, Ile, and Leu). EAA = Essential AA (Arg, His, Ile, Leu, Lys, Met, Phe, Thr, Trp, and Val). NEAA = Nonessential AA (Ala, Asn, Asp, Cys, Gln, Glu, Gly, Pro, Ser, and Tyr). TAA $=\mathrm{EAA}+\mathrm{NEAA}$.

\section{Lactation Responses}

The small increase in ME intake owing to casein and glucose infusions was compromised with a minor decrease in grass silage intake so that total DMI or ME intake did not change between the treatments (Table 2 ). Thus, the responses obtained in the present study can be related to the changes in the supply of infused nutrients. Infusions of casein and glucose either separately or in combination clearly increased yields of milk, protein and lactose in the present study. This indicates that neither the supply of AA nor glucose on the control diet was sufficient for potential milk production despite cows being near energy balance and calculated adequacy in total supply of AA. The colimitation of glucose and AA in the present dietary conditions may be more closely emphasized by comparing production responses of the combined and separate infusions of casein and glucose. With combined infusion increases in the yields of milk protein $(+138 \mathrm{~g} / \mathrm{d})$ and lactose $(+135 \mathrm{~g} / \mathrm{d})$ were nearly equal, whereas respective increases with separate casein infusion were $+117 \mathrm{~g} / \mathrm{d}$ for protein and +74 $\mathrm{g} / \mathrm{d}$ for lactose, and with separate glucose infusion +87 $\mathrm{g} / \mathrm{d}$ for protein and $+101 \mathrm{~g} / \mathrm{d}$ for lactose. It can be calculated that the separate casein infusion accounted for $85 \%$ of the achieved protein response $(117 / 138 \mathrm{~g} / \mathrm{d})$ and $64 \%$ of the achieved lactose response $(87 / 135 \mathrm{~g} / \mathrm{d})$, whereas the separate glucose infusion accounted for $54 \%$ of the protein and $75 \%$ of the lactose responses, respectively. The greater response of protein than lactose produced with casein suggests that insufficient glucose supply possibly limited production response with casein alone treatment, whereas the greater lactose than protein response produced with glucose suggests that insufficient AA supply limited further production response with glucose alone treatment. Either way, increased lactose yield associated with the separate casein infusion puts forward that part of the casein AA were used for glucogenic purposes, whereas increased protein yield associated with separate glucose infusion may be explained with improved utilization of AA from the basal diet in the presence of glucose by sparing AA from utilization for gluconeogenesis. 
Table 6. Least squares means for mammary arteriovenous difference ( $\mu \mathrm{mol} / \mathrm{L})$ of plasma AA.

\begin{tabular}{|c|c|c|c|c|c|c|c|c|}
\hline \multirow[b]{2}{*}{$\mathrm{AA}^{2}$} & \multicolumn{4}{|c|}{ Nutrients infused postruminally $^{1}$} & \multirow[b]{2}{*}{ SEM } & \multicolumn{3}{|c|}{$P$-value } \\
\hline & Control & $\mathrm{C}$ & $\mathrm{G}$ & CG & & $\mathrm{C}$ & $\mathrm{G}$ & $\mathrm{C} \times \mathrm{G}$ \\
\hline Arg & 30.9 & 36.4 & 20.2 & 26.2 & 5.82 & 0.36 & 0.12 & 0.97 \\
\hline His & 10.2 & 18.4 & 14.5 & 14.4 & 0.65 & 0.001 & 0.89 & 0.001 \\
\hline Ile & 32.9 & 55.2 & 48.6 & 54.0 & 2.45 & 0.001 & 0.03 & 0.01 \\
\hline Leu & 49.2 & 76.7 & 66.6 & 68.2 & 3.64 & 0.01 & 0.27 & 0.01 \\
\hline Lys & 42.8 & 64.3 & 56.4 & 58.0 & 1.88 & 0.001 & 0.10 & 0.001 \\
\hline Met & 11.3 & 15.7 & 15.1 & 14.1 & 0.86 & 0.10 & 0.25 & 0.02 \\
\hline Phe & 16.0 & 25.8 & 23.9 & 23.0 & 1.08 & 0.02 & 0.05 & 0.001 \\
\hline Thr & 18.6 & 34.7 & 32.4 & 33.8 & 4.37 & 0.09 & 0.19 & 0.15 \\
\hline Trp & 0.8 & 2.6 & 4.6 & 4.2 & 1.18 & 0.58 & 0.06 & 0.40 \\
\hline Val & 41.4 & 75.1 & 67.8 & 67.0 & 5.51 & 0.02 & 0.15 & 0.03 \\
\hline Ala & 23.0 & 36.9 & 55.2 & 41.0 & 9.34 & 0.99 & 0.10 & 0.18 \\
\hline Asn & 10.3 & 21.8 & 18.3 & 20.4 & 2.10 & 0.02 & 0.17 & 0.06 \\
\hline Asp & 2.7 & 3.3 & 3.0 & 3.0 & 0.48 & 0.51 & 0.94 & 0.56 \\
\hline Cit & -3.0 & 0.9 & 7.6 & 5.2 & 5.45 & 0.90 & 0.22 & 0.58 \\
\hline Cys & -0.3 & 2.4 & 2.4 & 1.7 & 0.74 & 0.24 & 0.23 & 0.07 \\
\hline Gln & 36.9 & 66.8 & 66.6 & 60.1 & 6.68 & 0.13 & 0.14 & 0.03 \\
\hline Glu & 38.1 & 43.6 & 41.6 & 38.6 & 2.17 & 0.59 & 0.74 & 0.10 \\
\hline Gly & -16.4 & 20.3 & 24.6 & 17.8 & 10.31 & 0.20 & 0.11 & 0.08 \\
\hline 3Methis & -0.6 & 0.1 & -0.3 & 0.2 & 0.22 & 0.04 & 0.38 & 0.53 \\
\hline Orn & 17.6 & 25.8 & 22.4 & 21.9 & 1.28 & 0.02 & 0.74 & 0.01 \\
\hline Pro & 7.8 & 23.2 & 16.8 & 23.8 & 3.09 & 0.01 & 0.17 & 0.23 \\
\hline Ser & -5.4 & 19.3 & 16.1 & 18.2 & 5.78 & 0.06 & 0.13 & 0.10 \\
\hline Tyr & 15.2 & 24.0 & 23.0 & 22.4 & 2.26 & 0.12 & 0.21 & 0.08 \\
\hline Tau & -0.6 & 3.4 & 3.4 & 3.0 & 0.97 & 0.11 & 0.11 & 0.06 \\
\hline BCAA & 123.5 & 207.0 & 182.9 & 189.2 & 10.48 & 0.01 & 0.09 & 0.01 \\
\hline EAA & 254.1 & 404.9 & 350.1 & 362.8 & 20.69 & 0.01 & 0.24 & 0.02 \\
\hline NEAA & 111.9 & 261.4 & 267.4 & 247.0 & 35.10 & 0.12 & 0.09 & 0.05 \\
\hline TAA & 366.0 & 666.3 & 617.5 & 609.8 & 52.97 & 0.03 & 0.12 & 0.03 \\
\hline
\end{tabular}

${ }^{1}$ Control = No infusion of nutrients; $\mathrm{C}=300 \mathrm{~g} / \mathrm{d}$ of casein infused postruminally; $\mathrm{G}=300 \mathrm{~g} / \mathrm{d}$ of glucose infused postruminally; $\mathrm{CG}=300 \mathrm{~g} / \mathrm{d}$ of casein and $300 \mathrm{~g} / \mathrm{d}$ of glucose infused postruminally.

${ }^{2}$ BCAA = Branched-chain AA (Val, Ile, and Leu). EAA = Essential AA (Arg, His, Ile, Leu, Lys, Met, Phe, Thr, Trp, and Val). NEAA = Nonessential AA (Ala, Asn, Asp, Cys, Gln, Glu, Gly, Pro, Ser, and Tyr). TAA $=\mathrm{EAA}+\mathrm{NEAA}$.

As also found in the present study, abomasal infusions of casein have repeatedly increased milk protein concentration, yields of milk, and protein on grass silage-based diets irrespective of the stage of lactation or silage fermentation type (Choung and Chamberlain, 1993a; Huhtanen et al., 1997; Vanhatalo et al., 2003). However, the response mechanism to casein have depended on silage fermentation type extensively fermented silage benefiting from increased supply of AA and restrictively fermented silage in addition to $\mathrm{AA}$ also more indirectly from increased supply of glucose (Huhtanen et al., 1997; Vanhatalo et al. 2003). Increased lactose yield and milk urea concentration with separate casein infusion in the present study are in line with this explanation.

Opposite to casein infusions production responses to glucose infusions on grass silage based diets have been inconsistent. Calculation of the supply of glucose according to stoichiometric principles described elsewhere (Huhtanen, 1998) proposed that supply of glucose on the control diet was about $90 \%$ of that required for the observed milk production in the present study. The infusions of $300 \mathrm{~g} / \mathrm{d}$ of glucose corresponded well with the calculated deficit of $285 \mathrm{~g} / \mathrm{d}$ of glucose and led to positive milk production responses being in good agreement with recent data (Hurtaud et al., 2000; Rigout et al., 2002). In contrast, glucose was not primarily limiting milk production of cows at midlactation (Kim et al., 2000; Vanhatalo et al., 2003). However, recent reports on significant production responses to intravascularly (Kim et al., 2001) or abomasally (Huhtanen et al., 2002) infused glucose, especially in the presence of His infusion, indicate that glucose alone was furthermore limited by lack of first-limiting AA in the diet. Therefore, reasons for the inconsistent responses to glucose infusions may lie not only in the stage of lactation (Vanhatalo et al., 2003) but also in the adequacy of other nutrients such as AA on the basal diet.

In contrast to earlier study (Huhtanen et al., 1997) milk fat concentration tended to decrease with casein infusion, probably reflecting the dilution of fat into the greater amount of milk produced with casein infusion. That glucose infusion did not affect milk fat concentration is in line with earlier studies, where relatively small amounts of glucose were infused (Kim et al. 2000; Huhtanen et al., 2002; Vanhatalo et al., 2003). Also, 
Table 7. Least squares means for extraction (arteriovenous difference/arterial concentration) of plasma AA by the mammary gland (\%).

\begin{tabular}{|c|c|c|c|c|c|c|c|c|}
\hline \multirow[b]{2}{*}{$\mathrm{AA}^{2}$} & \multicolumn{4}{|c|}{ Nutrients infused postruminally ${ }^{1}$} & \multirow[b]{2}{*}{ SEM } & \multicolumn{3}{|c|}{$P$-value } \\
\hline & Control & $\mathrm{C}$ & G & CG & & $\mathrm{C}$ & $\mathrm{G}$ & $\mathrm{C} \times \mathrm{G}$ \\
\hline Arg & 45.1 & 47.0 & 28.7 & 33.2 & 8.82 & 0.73 & 0.14 & 0.89 \\
\hline His & 45.6 & 40.2 & 56.3 & 30.9 & 3.91 & 0.01 & 0.87 & 0.04 \\
\hline Ile & 31.0 & 38.6 & 46.2 & 44.2 & 1.58 & 0.13 & 0.001 & 0.03 \\
\hline Leu & 47.6 & 52.4 & 62.9 & 50.9 & 3.36 & 0.32 & 0.09 & 0.05 \\
\hline Lys & 50.1 & 50.5 & 56.2 & 50.9 & 4.20 & 0.58 & 0.46 & 0.52 \\
\hline Met & 55.6 & 59.3 & 58.7 & 52.8 & 7.28 & 0.89 & 0.83 & 0.53 \\
\hline Phe & 37.1 & 49.3 & 50.2 & 46.1 & 3.75 & 0.32 & 0.23 & 0.07 \\
\hline Thr & 17.4 & 25.5 & 24.6 & 24.5 & 3.37 & 0.27 & 0.39 & 0.27 \\
\hline Trp & 3.5 & 8.6 & 15.7 & 13.5 & 3.81 & 0.71 & 0.07 & 0.38 \\
\hline Val & 20.5 & 26.4 & 33.0 & 26.0 & 2.04 & 0.81 & 0.02 & 0.02 \\
\hline Ala & 10.4 & 14.4 & 21.1 & 16.1 & 3.39 & 0.88 & 0.12 & 0.23 \\
\hline Asn & 19.5 & 30.6 & 28.2 & 30.4 & 3.72 & 0.12 & 0.30 & 0.28 \\
\hline Asp & 48.7 & 54.0 & 45.8 & 44.8 & 7.55 & 0.79 & 0.45 & 0.69 \\
\hline Cit & -3.6 & -8.3 & 5.6 & 5.2 & 8.15 & 0.76 & 0.21 & 0.80 \\
\hline Cys & -1.8 & 8.6 & 9.8 & 6.1 & 3.67 & 0.40 & 0.26 & 0.10 \\
\hline Gln & 17.5 & 27.7 & 24.2 & 24.0 & 2.65 & 0.11 & 0.58 & 0.10 \\
\hline Glu & 76.9 & 83.0 & 80.5 & 77.0 & 2.50 & 0.62 & 0.65 & 0.10 \\
\hline Gly & -4.9 & 6.6 & 7.3 & 5.3 & 2.97 & 0.16 & 0.11 & 0.06 \\
\hline 3Methis & -19.1 & 0.0 & -9.5 & 3.8 & 6.86 & 0.06 & 0.37 & 0.69 \\
\hline Orn & 41.0 & 39.4 & 45.6 & 39.4 & 3.31 & 0.28 & 0.51 & 0.51 \\
\hline Pro & 9.6 & 17.6 & 18.2 & 19.5 & 2.88 & 0.16 & 0.11 & 0.29 \\
\hline Ser & 0.9 & 15.7 & 14.1 & 16.2 & 3.46 & 0.05 & 0.09 & 0.12 \\
\hline Tyr & 35.6 & 39.4 & 44.6 & 38.6 & 5.48 & 0.85 & 0.48 & 0.41 \\
\hline Tau & -2.3 & 7.2 & 7.7 & 7.3 & 3.02 & 0.19 & 0.15 & 0.15 \\
\hline BCAA & 30.0 & 35.9 & 43.9 & 36.9 & 1.82 & 0.80 & 0.01 & 0.01 \\
\hline EAA & 31.8 & 37.4 & 41.3 & 36.2 & 2.46 & 0.84 & 0.14 & 0.07 \\
\hline NEAA & 10.7 & 20.6 & 20.8 & 19.1 & 2.62 & 0.17 & 0.15 & 0.07 \\
\hline TAA & 19.3 & 28.3 & 28.9 & 26.5 & 2.44 & 0.22 & 0.16 & 0.06 \\
\hline
\end{tabular}

${ }^{1}$ Control = No infusion of nutrients; $\mathrm{C}=300 \mathrm{~g} / \mathrm{d}$ of casein infused postruminally; $\mathrm{G}=300 \mathrm{~g} / \mathrm{d}$ of glucose infused postruminally; $\mathrm{CG}=300 \mathrm{~g} / \mathrm{d}$ of casein and $300 \mathrm{~g} / \mathrm{d}$ of glucose infused postruminally.

${ }^{2}$ BCAA = Branched-chain AA (Val, Ile, and Leu). EAA = Essential AA (Arg, His, Ile, Leu, Lys, Met, Phe, Thr, Trp, and Val). NEAA = Nonessential AA (Ala, Asn, Asp, Cys, Gln, Glu, Gly, Pro, Ser, and Tyr). TAA $=$ EAA + NEAA.

unchanged NEFA and insulin concentrations due to glucose infusions (Table 4 ) were in agreement with unchanged milk fat content.

\section{N Utilization}

The apparent $\mathrm{N}$ utilization (milk $\mathrm{N} /$ feed $\mathrm{N}$ ) were 29.0, $31.0,31.9$, and $32.7 \%$ for control, C, G, and CG treatments, respectively, proposing that infusion of casein and glucose both improved $\mathrm{N}$ utilization, though glucose more than casein ( +2.3 vs. $+1.4 \%$ units). Higher $\mathrm{N}$ utilization with glucose than casein increment was in accordance with the reduced milk urea concentration with glucose infusion ( $28.2 \mathrm{vs} .26 .7 \mathrm{mg} / \mathrm{dl})$, suggesting that a greater proportion of AA with glucose than casein was partitioned into milk or tissue synthesis. For casein infusion increases in arterial plasma and milk urea concentrations ( 4.9 vs. $5.5 \mathrm{~m} M ; 26.1$ vs. $28.8 \mathrm{mg} / \mathrm{dl}$, respectively), may be a consequence of the use of plasma AA for hepatic glucose synthesis. A tendency for increased plasma glucose concentration with infused casein supports this explanation. It should be noted, how- ever, that present improved $\mathrm{N}$ utilization with incremental casein is rather exceptional. Generally, in spite of the positive production responses to protein supplement incremental $\mathrm{N}$ source in the diet impairs $\mathrm{N}$ utilization.

The marginal increases in milk protein yields for casein infusions (C and CG treatments) were 0.44 and $0.52 \mathrm{~g} / \mathrm{g}$, being in the range of values reported for casein (see Choung and Chamberlain 1993a). The clearly higher transfer rate for casein in the presence of infused glucose is parallel with our recent study in which efficiency of utilization of the first-limiting AA, His, increased from 11 to $24 \%$ with increased supply of glucose (Huhtanen et al., 2002). The positive interaction between increased AA and glucose supply in milk production has also been obtained in production trials. Cows given incremental AA supply in terms of rapeseed meal and incremental gluconeogenic precursors in terms of wet distillers' solubles increased milk protein yield by 55 and $52 \mathrm{~g} / \mathrm{d}$ when given these supplements separately, but by $99 \mathrm{~g} / \mathrm{d}$ when given them simultaneously (Huhtanen et al., 1995). A similar tendency was found when 
supplementing restrictively fermented grass silage diet with incremental rapeseed meal and propylene glycol (Jaakkola et al., 1996). However, the same concept in another experiment (Shingfield et al., 2002) failed to result in a positive interaction. Lack of interaction was also found when supplementing corn silage-based diet with casein and propionic acid (Hurtaud et al., 1993). Differences in the lactation stage of cows in various experiments may explain contrasting results. It seems that positive responses to incremental AA in terms of casein (Hurtaud et al., 1993; Choung and Chamberlain 1993a, 1999b) or rapeseed meal (Saarisalo et al., 2002) can be expected even with well-fed cows at late stage of lactation producing less than $20 \mathrm{~kg}$ of milk per day, whereas positive responses to glucose supplement (present study; Hurtaud et al., 2000; Rigout et al., 2002) or interactions with AA and glucose supplements (present study; Huhtanen et al., 1995; Jaakkola et al. 1996) may rather be expected with cows at early stage of lactation producing more than 25 to $30 \mathrm{~kg}$ of milk per day. The positive responses related to increased AA supply irrespective of the production level may be due to qualitative improvements in amino acid profile of NAN entering to the intestines (Korhonen et al., 2002), whereas the positive responses to incremental glucose supply may be related to quantitatively increased glucose need especially at the early stage of lactation.

\section{Plasma Metabolites and AA}

Unchanged plasma insulin and NEFA concentrations as well as slight increases in arterial glucose due to infused nutrients were in line with other studies in which relatively small amounts of casein and glucose were infused (Kim et al., 2000; Vanhatalo et al., 2003). That arterial NEFA was relatively low lends support to the interpretation that cows, despite being in early stage of lactation, were near energy balance without any apparent need for mobilizing extra energy from body fat stores. As reviewed by Rigout et al. (2002) increases in insulin concentration is known to inhibit gluconeogenesis. Based on the unchanged insulin concentration and relatively small amounts of casein and glucose infused, it is probable that incremental nutrients did not decrease hepatic production of glucose in the present study. Even combined infusion of casein and glucose could not provide more than approximately $447 \mathrm{~g} / \mathrm{d}$ of incremental glucose assuming a glucose yield of $55 \mathrm{~g}$ from $100 \mathrm{~g}$ of AA (Krebs, 1964). However, decreased AV differences and extraction efficiencies of glucose due to added glucose refer to sufficient glucose supply on the CG treatment.

In spite of the production responses obtained, the relationship between glucose AV difference and arterial glucose concentration $\left(\mathrm{r}^{2}=0.34, \mathrm{n}=16\right)$ was relatively weak. This suggests that mammary glucose uptake is not necessarily dependent on arterial concentration, in contrast to previous findings with restrictively fermented grass silage (Miettinen and Huhtanen, 1997). The stable insulin concentration together with the higher plasma glucose concentration on the control diet in the present study may explain this. Decreased BHBA with glucose infusions may arise from the increased glucose supply. As reviewed by Ørskov et al. (1999), exogenous glucose has been attributed to antiketogenic effects.

Plasma AA concentration of cows fed grass silagecereal diets have been characterized with a low concentration of His (Vanhatalo et al., 1999; Kim et al., 2000; Korhonen et al., 2000). Increased plasma His as well as increased concentrations of other EAA with infused casein (Table 5) indicated increased supply of these AA for the metabolism of mammary gland in agreement with previous studies (Miettinen and Huhtanen, 1997; Vanhatalo et al., 2003). However, opposite to our previous findings present infusion of casein did not decrease concentration of NEAA, which together with increased plasma urea have been attributed to increased utilization of NEAA for glucose synthesis (Miettinen and Huhtanen, 1997; Vanhatalo et al., 2003). A possible reason for this discrepancy was that the proportion of propionate in the rumen on the control diet was presently higher than previously providing higher glucose supply.

Despite the fact that infused glucose did not affect arterial concentrations of AA, it did, however, increase plasma AV differences of these AA, although usually less than did infusion of casein $(P \geq 0.05$ for $\mathrm{C} \times \mathrm{G}$ interaction). This can be explained by higher extraction efficiencies of AA with glucose than with casein infusion over the control treatment $(P \geq 0.07$ for $\mathrm{C} \times \mathrm{G}$ interaction). Thus, as evidenced by increased protein yield with glucose treatment, it seems that by infusing glucose on grass silage diet it was possible to spare part of AA supply from utilization for gluconeogenesis. An alternative explanation for the increased protein yield with glucose infusion might be that AA present in excess could be secreted in greater amounts due to an increase in their transport in secretory vesicles, which is dependent on the colocation of the transport of lactose and protein in the mammary gland (Hurtaud et al., 2000).

As discussed in our recent paper (Huhtanen et al., 2002) calculating mammary plasma flow by Fick principle based on uptake and output of Phe and Tyr, should provide useful data on mammary metabolism of plasma nutrients. The reduced plasma flows due to infused nutrients in the present study obviously reflect improved balance in supply of limiting nutrients over the basal diet to meet glucose and AA needs of mammary 
gland for supporting the increased milk protein and lactose yields. The higher plasma flow with combined rather than separate infusions indicated, however, that as soon as availability of both of the limiting nutrients increased simultaneously a more optimal balance in supply of nutrients could be achieved by increasing mammary plasma flow. This was evidenced by further increased milk protein and lactose yields with the combined infusion of $\mathrm{C}$ and $\mathrm{G}$. The ability of mammary gland to adapt to changes in nutrient supply by regulating mammary blood flow has been demonstrated earlier in several studies (Bequette et al., 2000; Mackle et al., 2000; Huhtanen et al., 2002; Rigout et al. 2002).

\section{CONCLUSIONS}

Cows at early stage of lactation fed restrictively fermented grass silage diets appear to suffer from both limited glucose and AA supplies as indicated by partly additive increases in protein, lactose and milk yields achieved with abomasal infusions of casein and glucose. The casein-only associated response accounted for $85 \%$ of the protein yield attained, with combined glucose and casein infusion indicating that the potential protein yield could not be gained by only increasing AA supply. Part of the casein AA were likely used for glucogenic purposes as evidenced by increased lactose yield but also by increases in plasma urea and glucose concentrations. However, the glucose-only associated responses accounted for $75 \%$ of the lactose yield attained, with combined infusion of glucose and casein indicating that the potential lactose yield could not be gained by only increasing glucose supply when inadequate AA supply limited further production response. These data demonstrate that supplementing grass silage diet by appropriate AA and glucose supply, efficiency of use of nutrients particularly that of $\mathrm{N}$ can be improved. Further studies are needed to quantify lactational and metabolic responses as a function of graded amounts of added glucose on diets based on abundant use of restrictively fermented grass silage.

\section{ACKNOWLEDGMENTS}

The authors thank Aino Matilainen and Vesa Toivonen and their staff for skilled technical assistance in conducting the experiment. Financial support by Raisio Feed Ltd., 21201, Raisio, Finland, is also acknowledged.

\section{REFERENCES}

Ahvenjärvi, S., A. Vanhatalo, P. Huhtanen, and T. Varvikko. 1999. Effects of supplementation of a grass silage and barley diet with urea, rapeseed meal and heat-moisture-treated rapeseed cake on omasal digesta flow and milk production in lactating dairy cows. Acta Agric. Scand., Sect. A. Anim. Sci. 49:179-189.
Bequette, B. J., M. D. Hanigan, A. G. Calder, C. K. Reynolds, G. E. Lobley, and J. C. Mac Rae. 2000. Amino acid exchange by the mammary gland of lactating goats when histidine limits milk production. J. Dairy Sci. 83:765-775.

Choung, J.-J., and D. G. Chamberlain. 1993a. The effects of abomasal infusions of casein or soya-bean-protein isolate on the milk production of dairy cows in mid-lactation. Br. J. Nutr. 69:103-115.

Choung, J.-J., and D. G. Chamberlain. 1993b. Effects of addition of lactic acid and post-ruminal supplementation with casein on the nutritional value of grass silage for milk production in dairy cows. Grass Forage Sci. 48:380-386.

Clark, J. H., T. H. Klusmeyer, and M. R. Cameron. 1992. Microbial protein synthesis and flows of nitrogen fractions to the duodenum of dairy cows. J. Dairy Sci. 75:2304-2323.

Danfær, A., V. Tetens, and N. Agergaard. 1995. Review and an experimental study on the physiological and quantitative aspects of gluconeogenesis in lactating ruminats. Comp. Biochem. Physiol. 111B:201-210.

Huhtanen, P. 1998. Supply of nutrients and productive responses in dairy cows given diets based on restrictively fermented silage. Agric. Food Sci. Finl. 7:219-250.

Huhtanen, P., R. Blauwiekel, and I. Saastamoinen. 1998. Effects of intraruminal infusions of propionate and butyrate with two different protein supplements on milk production and blood metabolites in dairy cows receiving grass silage-based diet. J. Sci. Food Agric. 77:213-222.

Huhtanen, P. J., S. Jaakkola, and E. Saarisalo. 1995. The effects of concentrate energy source on the milk production of cows given a grass silage-based diet. Anim. Sci. 60:31-40.

Huhtanen, P. J., H. O. Miettinen, and V. F. J. Toivonen. 1997. Effects of silage fermentation and post-ruminal casein supplementation in lactation dairy cows: 1 - Diet digestion and milk production. J. Sci. Food Agric. 74:450-458.

Huhtanen, P., A. Vanhatalo, and T. Varvikko. 2002. Effects of abomasal infusions of histidine, glucose, and leucine on milk production and plasma metabolites of dairy cows fed grass silage diets. J. Dairy Sci. 85:204-216.

Hurtaud, C., S. Lemosquet, and H. Rulquin. 2000. Effects of graded duodenal infusions of glucose on yield and composition of milk from dairy cows. 2. Diets based on grass silage. J. Dairy Sci. 83:2952-2962.

Hurtaud, C., H. Rulquin, and R. Verite. 1993. Effect of infused volatile fatty acids and caseinate on milk composition and coagulation in dairy cows. J. Dairy Sci. 76:3011-3020.

Jaakkola, S., M. Rinne, T. Heikkilä, V. Toivonen, and P. Huhtanen. 1996. Effects of restriction of silage fermentation with formic acid on milk production. Pages 76-77 in Proc. 11th Int. Silage Conf. Univ. of Wales, D. I. H. Jones, R. Jones, R. Dewhurst, R. Merry and P. M. Haigh, ed. IGER, Aberystwyth, UK.

Kim C.-H., J.-J. Choung, and D. G. Chamberlain. 1999. Determination of the first-limiting amino acid for milk production in dairy cows consuming a diet of grass silage and a cereal-based supplement containing feather meal. J. Sci. Food Agric. 79:1703-1708.

Kim, C.-H., J.-J. Choung, and D. G. Chamberlain. 2000. The effects of intravenous administration of amino acids and glucose on the milk production of dairy cows consuming diets based on grass silage. Grass Forage Sci. 55:173-180.

Kim, C.-H., T.-G. Kim, J.-J. Choung, and D. G. Chamberlain 2001. Effects of intravenous infusion of amino acids and glucose on the yield and concentration of milk protein in dairy cows. J. Dairy Res. 68:27-34.

Korhonen, M., A. Vanhatalo, T. Varvikko, and P. Huhtanen. 2000. Responses to graded postruminal doses of histidine in dairy cows fed grass silage diets. J. Dairy Sci. 83:2596-2608.

Korhonen, M., A. Vanhatalo, and P. Huhtanen. 2002. Effect of protein source on amino acid supply, milk production, and metabolism of plasma nutrients in dairy cows fed grass silage. J. Dairy Sci. 85:3336-3351.

Krebs, H. A. 1964. The metabolic fate of amino acids. Pages 125-177 in Mammalian Protein Metabolism. Vol. 1. H. A. Munro, and J. B. Allison eds. Academic Press, New York, NY. 
Mackle, T. R., D. A., Dwyer, K. L. Ingvartsen, P. Y. Chouinard, D. A. Ross, and D. E. Bauman. 2000. Effects of insulin and postruminal supply of protein on use of amino acids by the mammary gland for milk protein synthesis. J. Dairy Sci. 83:93-105.

Miettinen, H.O., and P. J. Huhtanen. 1997. Effects of silage fermentation and post-ruminal casein supplementation in lactating dairy cows: 2-Energy metabolites and plasma amino acids. J. Sci. Food Agric. 74:459-468.

Ørskov, E. R., D. E. Meehan, N. A. MacLeod, and D. J. Kyle. 1999. Effect of glucose supply on fasting nitrogen excretion and effect of level and type of volatile fatty acid infusion on response to protein infusion in cattle. Br. J. Nutr. 81:389-393.

Rigout, S., S. Lemosquet, J. E. van Eys, J. W. Blum, and H. Rulquin. 2002. Duodenal glucose increases glucose fluxes and lactose synthesis in grass silage-fed dairy cows. J. Dairy Sci. 85:595-606.

SAS User's Guide: Statistics. Version 6.12 Edition. 1996. SAS Inst. Inc., Cary, NC.

Saarisalo, E., S. Jaakkola, and P. Huhtanen. 2002. Effects of supplementing grass silage with protein on production of primiparous cows in late lactation. Page 594 in Multi-function Grasslands, Quality Forages, Animal Products and Landscapes. Proc. 19th General. Mtg Europ. Grassland Fed. J.-L. Durand et al. ed. La Rochelle, France.
Shingfield, K. J., S. Jaakkola, and P. Huhtanen. 2002. Effect of forage conservation method, concentrate level and propylene glycol on diet digestibility, rumen fermentation, blood metabolite concentrations and nutrient utilisation of dairy cows. Anim. Feed Sci. Technol. 97:1-21.

Sjaunja, L. O., L. Baevre, L. Junkkarinen, J. Pedersen, and J. Setälä. 1990. A Nordic proposal for an energy corrected milk (ECM) formula. Pages 156-157 in 27th Session Int. Comm. Recording and Productivity of Milk Animals. Paris, France.

Tuori, M., K. Kaustell, J. Valaja, E. Aimonen, E. Saarisalo, and P. Huhtanen. 2000. Rehutaulukot ja ruokintasuositukset. (Feed Tables and Feeding Recommendations). 3rd ed. Yliopistopaino, Helsinki, Finland.

Vanhatalo, A., P. Huhtanen, V. Toivonen, and T. Varvikko. 1999 Response of dairy cows fed grass silage diets to abomasal infusions of histidine alone or in combinations with methionine and lysine. J. Dairy Sci. 82:2674-2685.

Vanhatalo, A., P. Huhtanen, and T. Varvikko. 2003. Effect of various glucogenic sources on production and metabolic responses of dairy cows fed grass silage based diets. J. Dairy Sci. 86:3249-3259.

Varvikko, T., A. Vanhatalo, T. Jalava, and P. Huhtanen. 1999. Lactation and metabolic responses to graded abomasal doses of methionine and lysine in cows fed grass silage diets. J. Dairy Sci. 82:2659-2673. 